\title{
Use of biotic indices in semi-enclosed coastal ecosystems and transitional waters habitats-Implications for the implementation of the European Water Framework Directive
}

\author{
H. Blanchet ${ }^{a},{ }^{*}$, N. Lavesque ${ }^{a}$, T. Ruellet $^{\text {b, c }}$, J.C. Dauvin $^{\text {b, c }}$, P.G. Sauriau ${ }^{d}$, N. Desroy ${ }^{e}$, C. \\ Desclaux $^{a}$, M. Leconte ${ }^{a}$, G. Bachelet ${ }^{a}$, A.-L. Janson ${ }^{b},{ }^{c}$, C. Bessineton ${ }^{\dagger}$, S. Duhamel ${ }^{f}, J$. \\ Jourde ${ }^{f}$, S. Mayot ${ }^{g}$, S. Simon ${ }^{g}$ and X. de Montaudouin ${ }^{a}$
}

\footnotetext{
a Université Bordeaux 1, CNRS, UMR 5805 EPOC, Station Marine d'Arcachon, 2 Rue du Professeur Jolyet, 33120 Arcachon, France

b Université des Sciences et Technologies Lille 1, CNRS FRE 2816 ELICO, Station Marine de Wimereux, 28 Avenue Foch, BP 80, 62930 Wimereux, France

${ }^{c}$ Groupement d'Intérêt Public Seine-Aval, 12 Avenue Aristide Briand, 76000 Rouen, France

d Université de La Rochelle, CNRS, IFREMER, UMR 6217 CRELA, Place du Séminaire, BP 5, 17137 L'Houmeau, France

${ }^{\mathrm{e}}$ IFREMER, Laboratoire Environnement et Ressources de Saint-Malo, 2 bis Rue Grout de Saint-Georges, BP 46, 35042 Saint-Malo Cedex, France

${ }^{\mathrm{f}}$ Maison de l'Estuaire, 20 Rue Jean Caurret, 76600 Le Havre, France

${ }^{9}$ Cellule de Suivi du Littoral Haut Normand, 16 Quai Casimir Delavigne, 76600 Le Havre, France
}

*: Corresponding author : H. Blanchet, email address : $\underline{\text { h.blanchet@epoc.u-bordeaux1.fr }}$

\begin{abstract}
:
This study deals with the application of macrozoobenthos-based biotic indices (BI) within the frame of the implementation of the European Water Framework Directive. More precisely, this study aimed at assessing the performance of five recently developed methodologies (BI) for the assessment of ecological quality status (EcoQ) in two semi-enclosed, sheltered coastal ecosystems and in one transitional water body situated along the Western French coast, namely Marennes-Oléron Bay, Arcachon Bay, and the Seine Estuary. This study showed that these five indices rarely agreed with each other, describing very different pictures of the overall EcoQ of the three study sites. This work also clearly underlined the limitations of these approaches, notably the dependency of most of these $\mathrm{BI}$ and the resulting EcoQ classifications on habitat characteristics, more particularly to natural levels of sediment silt-clay content and the location of stations in the subtidal or the intertidal. The implication of our observations concerning the use of these BI for implementation of the WFD is discussed in terms of definition of habitat-specific reference conditions and necessity to adjust thresholds to the particular habitat occurring in semi-enclosed ecosystems. Meanwhile, the unmodified use of these BI severely impaired accurate assessment of EcoQ and decision-making on the managers' point of view.
\end{abstract}

Keywords: Biotic index; European Water Framework Directive; Benthic invertebrates; Semi-enclosed coastal ecosystems; Transitional waters 


\section{Introduction}

Since the publication in 2000 of the European Water Framework Directive (WFD), the interest of European marine ecologists for the bio-assessment of human impact on littoral ecosystems has been renewed (Simboura, 2004; Borja, 2005; Borja and Heinrich, 2005; Dauvin, 2005, 2007). Indeed, European Union countries are now bound to assess and monitor the quality of their surface and ground-water bodies through the survey of a set of physical, chemical and biological quality elements defined in the Annex V of the WFD. Among these biological quality elements, benthic invertebrates are used for assessing the ecological quality status (EcoQ) of surface water bodies including coastal and transitional (estuaries) water bodies. As a consequence, numerous bio-assessment tools have been developed or adapted to the WFD requirements in recent years (Borja et al., 2000; Simboura and Zenetos, 2002; Rosenberg et al., 2004; Dauvin and Ruellet, 2007), notably in the field of benthic invertebrate ecology (Diaz et al., 2004) because these organisms are generally considered as potentially powerful indicators of aquatic ecosystems health (Beukema and Cadée, 1986; Warwick, 1986; Dauvin, 1993). Indeed, they are situated at the interface between sediment and water column and thus integrate the characteristics of both sub-systems. Moreover, they may give evidence of environmental changes because of their sedentary life preventing them to escape unfavourable conditions and their relatively long lifespan permitting to discriminate between accidental and chronic disturbances (Dauvin, 1993; Reiss and Kröncke, 2005). Finally, in comparison to a chemical approach which consists in measuring pollutant concentrations in water or sediments and comparing them to existing norms, studying benthic invertebrate community can detect real ecological impact of disturbances at the community and ecosystem levels (Fano et al., 2003). Although a large corpus of synecological methodologies has been 
developed throughout the world to describe community structure and dynamics (Diaz et al., 2004), the current study only concerns a set of univariate biotic indices (BI) supposed to be adapted to fulfil the requirement of the WFD. In this paper, the behaviour of these BIs was tested in semi-sheltered littoral ecosystems. Indeed, most of the BIs proposed to the WFD and addressed in this paper are based on works which concern open marine subtidal areas and their sensitivity to increasing organic matter inputs (Pearson and Rosenberg, 1978; Bellan, 1993; Grall and Glémarec, 1997). Consequently, one can wonder whether these BIs would correctly perform in freshwater-influenced, semi-enclosed environments where sediments are naturally dominated by mud and/or organic carbon, and where intertidal areas can represent a dominant part of the whole area.

The objectives of this study were (1) to test the applicability of a set of currently available univariate BIs for the EcoQ status assessment of three semi-enclosed (two coastal and one estuarine) ecosystems and (2) to evaluate BI dependency on sediment characteristics and immersion/emersion. 


\section{Materials and Methods}

\section{Study sites}

The three study sites are situated along the western French coast (Fig. 1). Two sites (Arcachon Bay and Marennes-Oléron Bay) are located in the Bay of Biscay and one (Seine Estuary) in the Eastern English Channel. All sites were characterised by the dominance of soft bottoms, shallow depth and tidal regime.

\section{Seine Estuary}

The Seine Estuary is a $50 \mathrm{~km}^{2}$ macrotidal estuary (maximum tidal range: $8.5 \mathrm{~m}$ ). It opens into the English Channel (Fig. 1a). This estuary ranks among the three largest estuaries in France together with the Loire $\left(60 \mathrm{~km}^{2}\right)$ and the Gironde $\left(625 \mathrm{~km}^{2}\right)$. Mean flow rate is $410 \mathrm{~m}^{3} \mathrm{~s}^{-1}$ with a maximum of $2000 \mathrm{~m}^{3} \mathrm{~s}^{-1}$ (decennial flood) and a minimum of $81 \mathrm{~m}^{3} \mathrm{~s}^{-1}$ during low river flow (Mouny et al., 1998; Dauvin et al., 2005, 2007). Turbidity reaches up to $100 \mathrm{~g} \mathrm{~L}^{-1}$. A salinity gradient can be observed from polyhaline waters (salinity: 30 to 18) at the opening of the estuary toward oligohaline waters (Desroy and Dauvin, 2003). Sampling stations were situated in the polyhaline and downstream mesohaline zones with a majority of stations (99 out of 111) restricted to the polyhaline zone. Intertidal flats do not reach extended areas in this estuary. This estuary is highly industrialised and urbanised gathering $26 \%$ of the French population and $40 \%$ of national industrial activities together with areas of intensive agriculture in its $79000 \mathrm{~km}^{2}$ catchment area. Moreover, it has been heavily modified by the development of two major harbours (Le Havre and Rouen) and the estuarine part has been channelled and is regularly dredged (Dauvin et al., 2005). The level of various contaminants is high in water and sediments, classifying this estuary as one of the most contaminated in Europe (Dauvin et al., 2005, 2007). 


\section{Marennes-Oléron Bay}

The Marennes-Oléron Bay is a $175 \mathrm{~km}^{2}$ macrotidal semi-enclosed coastal system which is situated between the Oléron Island to the West and the continent to the East (Fig. 1b). The bay presents shallow depth $(<20 \mathrm{~m}$ depth $)$ and is characterised by large intertidal mudflats covering $60 \%$ of the total area. These flats are mostly unvegetated except on the east coast of the Oléron Island where Zostera noltii seagrass beds occur. The bay communicates with the ocean by two openings situated at its southern (Maumusson Pertuis) and northern (Antioche Pertuis) parts. It also receives freshwater inputs $\left(3 \times 10^{9} \mathrm{~m}^{3} \mathrm{yr}^{-1}\right)$ by the Charente river which gives $90 \%$ of total freshwater inputs (Héral et al., 1978, 1984). Marennes-Oléron Bay is a major French site for oyster and mussel cultures. The level of contamination is relatively low; however Cd concentrations may be problematic (Pigeot et al., 2006).

\section{Arcachon Bay}

Arcachon Bay is a $180 \mathrm{~km}^{2}$ meso- to macrotidal (maximum tidal range: $4.9 \mathrm{~m}$ ) coastal lagoon situated in the south-eastern Bay of Biscay (Bachelet et al., 1996) (Fig. 1c). This triangularshaped lagoon communicates with the Atlantic Ocean through a natural channel and receives its main freshwater inputs by a small river (L'Eyre) situated on its south-eastern corner (Fig. 1c). The maximum depth reaches about $24 \mathrm{~m}$ at the entrance of the lagoon; however, most channels displayed shallower depth $(<20 \mathrm{~m})$. Salinity varies from the fully marine waters at the entrance and western part of the Bay to more briny waters (salinity 22-32) toward the inner parts of the lagoon. As the Marennes-Oléron Bay, this lagoon is characterised by large intertidal flats covering $70 \%$ of the bay area. The largest and most flourishing Zostera noltii seagrass bed of Europe (Auby and Labourg, 1996) covers these flats. The lower part of the intertidal is generally devoted to oyster culture, which constitutes a major activity at this site. Owing to the building in the late 1960s of a large sewage collector system that connects the towns and industries situated on its coast, and of the low level of industrialisation of its 
catchment area, the waters of the lagoon are relatively clean. Despite some signs of moderate eutrophication (e.g. large development of green macroalgae in the early 1990s) the overall water quality of the lagoon is considered as satisfying (Castel et al., 1996; Bachelet et al., 2000).

\section{Databases}

Three databases, each corresponding to one of the study sites, were used in this study. Each database gathered data on soft-bottom macrofauna sampled with a 1-mm mesh sieve during different studies and scientific programs (except some stations sieved on 2-mm mesh in the Seine Estuary). The characteristics of the datasets are shown in Table 1.

Concerning the Seine Estuary, data were extracted form the MABES database which gathers data from the Bay of Seine and the Seine Estuary collected during various sampling campaigns (Dauvin et al., 2007). The dataset consisted of 111 subtidal stations located throughout the estuary and sampled on a single occasion (Table 1). The datasets from Marennes-Oléron Bay and Arcachon Bay consisted of 262 and 177 stations, respectively, each set from one sampling campaign (Table 1). In contrast with the data from the Seine Estuary, these two latter datasets included stations located on intertidal and subtidal areas.

\section{Biotic indices and Derivation of EcoQ}

Five different BIs were calculated when possible for each station of the databases, namely the AMBI (Borja et al., 2000), BENTIX (Simboura and Zenetos, 2002; Simboura et al., 2005; Simboura and Reizopoulou, 2007), BQI (Rosenberg et al., 2004), Shannon-Wiener diversity (Simboura and Zenetos, 2002; Labrune et al., 2005) and BOPA (Dauvin and Ruellet, in press). These BIs were chosen because they are proposed to be used in the WFD.

AMBI, BENTIX and BOPA indices are based on the classification of species (or groups of species) into several ecological groups representing species level of sensitivity to pollutions. The number of ecological groups varied according to each index ( 5 for the AMBI, 2 for the 
BENTIX and the BOPA). AMBI identifies five ecological groups corresponding to most sensitive species (ecological group 1) to most opportunistics / tolerant species (ecological group 5). BENTIX only recognised two groups (sensitive and opportunistic species), corresponding to ecological groups 1-2; and ecological groups 3 to 5, respectively, of the AMBI. BOPA considers the ratio between opportunistic polychaetes (i.e. polychaetes from ecological groups 4 and 5 of the AMBI) and amphipods (except those from the genus Jassa) as an indicator of environment quality. Full computational details can be found in Borja et al. (2000), Simboura and Zenetos (2002), Dauvin and Ruellet (2007) and are reported in Table 2. Shannon index was also used as an indicator of EcoQ by Simboura and Zenetos (2002) and Labrune et al. (2005) and corresponding EcoQ classes from these studies were used. BQI calculation incorporates two measures: (1) the species' specific tolerance value $\left(\operatorname{ES}(50)_{0.05}\right)$ which is a measure of each species sensitivity or tolerance to pollutions, and (2) the diversity of the benthic assemblage estimated through the number of species collected in the sample. The index computes the relative abundance of each species together with their own tolerance value to the sample number of species. Computational details can be found in Rosenberg et al. (2004) and are also reported in Table 2. To apply this index to our study sites, the expected number of species in a random sample of 50 indviduals (ES(50) (Hurlbert, 1971)) was calculated for each sampled station and the tolerance value $\left(\operatorname{ES}(50)_{0.05}\right)$ of each species was determined separately for each of the three study sites as recommended by Rosenberg et al. (2004) and Labrune et al. (2005). The EcoQ assessed by BQI was determined by taking the highest BQI value as a reference value and by defining five classes of equal size between 0 and this reference value (Rosenberg et al., 2004). Due to the difference in the range of index values between intertidal and subtidal stations, a separate scale was used for intertidal and subtidal sites following the same trend than Rosenberg et al. (2004). These separate scales 
permitted to avoid classifying all intertidal sites as severely degraded. The EcoQ classes in which index values were classified are shown in Table 3.

\section{Data analysis}

Agreement/disagreement between the five BIs was determined by considering only two EcoQ status: 'acceptable' or 'not acceptable'. 'Acceptable' status was determined for each BI when the derived EcoQ status was 'High' or 'Good', and scored as ' 1 '. This means that, on the managers point of view, no action has to be taken to restore the ecosystem. 'Not acceptable' status corresponded to 'Moderate', 'Poor' or 'Bad' EcoQ status, and was scored as '0'. When such an EcoQ status is derived from the biotic index, restoration measures are to be taken in order to reach 'Good' status by 2015 as stated by the WFD. The scores given to each of the five BI used were summed for each station (range: 0-5). This sum of scores allowed measuring the level of agreement/disagreement between BIs (Table 4).

A non-parametric sign-test was also used to assess agreement or disagreement between the different BIs on the 'acceptable' - 'not acceptable' status of stations on a statistical basis. This non-parametric test was particularly adapted to our data as it allowed to compare related sample classifications based on nominal data ('acceptable' - 'not acceptable') (Siegel, 1956).

Correlation between indices-derived classifications of EcoQ was studied in order to assess whether the different indices displayed similar tendency in the classification of stations. In summary, it permitted to assess if two indices ranked the stations from worst to best in the same way regardless of the precise classes of EcoQ. Indeed two given indices may not classify stations along the same range of EcoQ classes: one index may assess a given set of stations in EcoQ ranging from 'High' to 'Moderate' whereas another may assess the same set along a 'High' to 'Bad' range. For this test, EcoQ classes were ranked from 1 which corresponded to 'High' EcoQ, to 5, corresponding to 'Bad' EcoQ. Owing to the nature of data (five EcoQ classes), correlations between indices-based classifications were tested on the 
basis of ranks through the use of the non-parametric Kendall's rank-correlation coefficient $\tau$. Ties were taken into account in the computation of $\tau$ by using the correction factor recommended by statisticians (Siegel, 1956; Scherrer, 1984). The significance of $\tau$ was tested according to Siegel (1956).

For Marennes-Oléron Bay and Arcachon Bay, the non-parametric Kruskal-Wallis test was used to detect significant differences in environmental conditions between stations classified into the different EcoQ classes by the five BI. Variables used in the analysis were duration of emersion (in number of days per year) and sediment silt-clay content (in \%). The test was first performed on the full site database to assess significant variations in environmental conditions between EcoQ classes. On a second run, subtidal and intertidal stations were analysed separately to circumvent correlation between sediment silt \& clay content and the tidal location of stations. For each tidal location, the linear regression between indices value and silt-clay content was calculated and the significance of the linear coefficient of determination $\left(\mathrm{R}^{2}\right)$ was tested. This approach could not be used with the Seine Estuary because sediment characteristics were not systematically studied at all sampled stations. 


\section{Results}

\section{EcoQ classifications}

Use of the different BIs gave a different pattern of the overall EcoQ of the investigated sites (Fig. 2). The BOPA classified a large majority of stations ( $>97 \%)$ as 'acceptable' in both coastal systems and in the Seine Estuary. In the same way, the AMBI classified the Seine Estuary, Marennes-Oléron Bay and Arcachon Bay stations as 'acceptable' in 100\%, 95\% and $88 \%$ of cases, respectively. However the AMBI classified a majority of stations as 'Good' (86\% and 76\% for Marennes-Oléron Bay and Arcachon Bay, respectively) whereas BOPA classified stations predominantly as 'High' (with 65 to $60 \%$ of stations in both coastal systems) (Fig. 2a and 2b).

The classification of stations by the BENTIX index was more 'severe' with 43 and $36 \%$ of stations considered as 'not acceptable' (i.e. 'Moderate' EcoQ status or worse) in MarennesOléron Bay and Arcachon Bay, respectively. In the Seine Estuary, the percentage of stations considered as 'not acceptable' was only 10\%. 'Bad' and 'Poor' status rarely occurred (Fig. 2). Shannon diversity classified $37 \%$ of the stations in Arcachon Bay, 53\% in Marennes-Oléron Bay, and $95 \%$ in the Seine Estuary as 'not acceptable' (Fig. 2). In both coastal ecosystems, the Shannon index identified as 'Poor' or 'Bad' $7 \%$ and $12 \%$ of the stations in Arcachon Bay and Marennes-Oléron Bay, respectively (Fig. 2a and 2b). In the Seine Estuary, the Shannon index classified $58 \%$ of stations as 'Poor' or 'Bad', whereas BOPA and AMBI never identified such status in this estuary.

The proportion of stations classified as 'not acceptable' by the BQI was similar to that of the Shannon index, with $57 \%$ of the stations in the coastal systems and $95 \%$ in the Seine Estuary classified as 'Moderate' or worse. BQI assessed 'Poor' status in 19 and 20\% of stations in Marennes-Oléron Bay and in Arcachon Bay, respectively. No station were considered as 
'Bad' by the BQI in these two coastal sites whereas 33\% of stations of the Seine Estuary were classified as 'Bad' and $40 \%$ as 'Poor'.

\section{Agreement/disagreement between indices}

When considering spatial variations, the different BIs disagreed on the status of 65 to $90 \%$ of the stations (Fig. 3). The different BIs fully agreed on the 'acceptable' or 'not acceptable' status in less than $2 \%$ of stations. Partial agreement (i.e. 4 indices out of 5 agreed on 'acceptable' or 'not acceptable') occurred in 33\% of stations in Marennes-Oléron Bay, $36 \%$ in Arcachon Bay and only 8\% in the Seine Estuary (Fig. 3). The general disagreement between indices was confirmed by the sign test (Table 5). Nevertheless there was no significant disagreement between BOPA and AMBI classifications in Marennes-Oléron Bay and the Seine Estuary and only a significant difference (at a level of significance $=0.05$ ) in Arcachon Bay. BENTIX and BQI moreover significantly agreed in Marennes-Oléron Bay, BENTIX and Shannon in Arcachon Bay and BQI and Shannon in the Seine Estuary (Table 5).

When considering the five EcoQ classes, most indices, with the noteworthy exception of the BOPA, showed significant correlations with each others (Tables 6 and 7). It meant that the BENTIX, BQI, Shannon diversity and AMBI indices basically ranked stations in the same way from worst EcoQ to best EcoQ. However, these results showed that BENTIX, BQI, AMBI and Shannon index basically differed in the range of EcoQ assessed to stations. As an example, using the same set of stations, AMBI would classify these stations from 'High' to 'Good' whereas BENTIX, Shannon index or BQI would classify this same set from 'High' to 'Bad' and that stations classified as 'Bad' by the latter BI corresponded to stations classified as 'Moderate' by the first BI. As a result, a manager's decision is highly dependent on the BI used to assess the EcoQ. 


\section{Sources of variations in semi-enclosed coastal ecosystems}

Kruskal-Wallis' test showed that there was a significant difference of both sediment silt - clay content and duration of emersion between EcoQ classes assessed by the AMBI, the BENTIX and the Shannon index (Table 8). There was a significant linear positive correlation $(\mathrm{p}<0.05)$ between AMBI values and silt - clay content. However this hardly modified the decision between 'acceptable' and 'not acceptable'. In Arcachon Bay, the index values were also higher and the EcoQ classification worsened (Kruskall-Wallis test, $\mathrm{p}>0.05$, Table 8) in the intertidal compared to the subtidal. As a consequence, stations situated on the muddy sediments associated to Zostera noltii seagrass beds displayed poorest EcoQ (Fig. 4).

The behaviour of BENTIX was similar to that of AMBI, except that duration of emersion played a significant role in both coastal ecosystems. Intertidal sites were indeed considered as more degraded by this BI than in the subtidal leading to the classification of many intertidal stations as 'Moderate' or worse (Fig. 4). Moreover, BENTIX was more sensitive to vegetation cover, placing the Z. noltii stations in a 'not acceptable' situation (Fig. 4).

Shannon index displayed a non-linear response to sediment silt and clay content (Fig. 4). Indeed, the EcoQ status slightly improved (although $\mathrm{R}^{2}$ remain low) with silt and clay content but its value dropped with highest sediment silt \& clay content (Fig. 4).

Except for the intertidal stations of Marennes-Oléron Bay where sediments did not modify the index value, BQI roughly behaved as BENTIX (and, to a lesser extent, as AMBI) but with this BI generally assessed poorer EcoQ than the two latter BI (Fig. 4).

In contrast with the other indices, BOPA assessed High EcoQ to the majority of stations in both bays, with hardly any correlation with silt - clay content (Fig. 4). 


\section{Discussion}

The overall pattern of ecological quality status was very different according to the biotic index selected. As an example, according to the BOPA, most sites should be considered as displaying 'High' Ecological Quality status while Shannon index or BQI provided a much more degraded situation in all three sites, especially in the transitional waters of the Seine Estuary when considering the entire databases. With such a simplistic approach, the use of the five different biotic indices to describe the EcoQ added more complexity than clarity, impairing the accurate assessment of the EcoQ status of the benthic invertebrate communities. Such a problem was also identified by Quintino et al. (2006) in a study including three estuarine and coastal areas of the western coast of Portugal and by Labrune et al. (2006) in the Gulf of Lions. Indeed, our data showed that the classifications of EcoQ status derived from each index rarely agreed on a managerial point of view (i.e. 'acceptable' vs 'not acceptable' situations). However when considering the five EcoQ classes of the WFD, correlation's were generally significant with the noteworthy exception of the BOPA. It means that the AMBI, BENTIX, Shannon and BQI indices generally ranked stations in the same way but disagreed on the precise level of EcoQ assessed to each station by the different indices. Correlations between AMBI and BENTIX variations could be easily explained by the computational details of these indices. Both indices are based on the classification of species into ecological groups reflecting species sensitivity, tolerance or opportunism. AMBI considered five groups whereas BENTIX considered only two groups with ecological groups 1 and 2 of the AMBI in the first group, and groups 3, 4 and 5 of the AMBI in the second group (Borja et al. 2000; Simboura and Zenetos, 2002). Conversely, BQI and Shannon index are more or less directly based on alpha diversity measures, namely ES (50) and number of species, and the Shannon-Wiener diversity index, respectively. As a consequence, BQI values are closely related to diversity measures including dominance as stated by Labrune et al. (2006). When using our data, relationships between BQI and ES (50) values also proved to be very strong with a highly significant $R^{2}$ value of 0.753 between ES (50) and BQI, and a highly significant $\mathrm{R}^{2}$ value of 0.618 between Shannon index values and BQI (not shown). Disagreement between the BQI and Shannon index mainly consisted into a different definition of thresholds between EcoQ classes. Correlation between BENTIX and Shannon 
index was more surprising as both indices do not account for the same variables. This correlation could be explained by the numerical dominance of a few species (such as Hydrobia ulvae) in intertidal muddy sites. The dominance pattern lowers the value of the Shannon index and the EcoQ derived from BENTIX as these dominant species belong to the tolerant/opportunist species considered by the BENTIX (ecological group 3 of the AMBI).

As a general result our study showed that habitat characteristics such as sediment silt and clay content and the interidal or subtidal location of stations had significant influence on the EcoQ classification of stations by most of the BI studied here. In particular, intertidal and muddy stations were ranked as more degraded by most indices with the noteworthy exception of the BOPA. These parameters are known as key-factors structuring the benthic macrofauna and should thus be taken into account in any attempt of EcoQ assessment through the use of benthic community structure and composition. This study showed that habitat-related specificity must be taken into account, especially the sediment silt clay content and the intertidal or subtidal location of habitat. In semi-enclosed environment, biotic index classifications varied according to the silt - clay content of the sediment. This result was not really surprising considering the historical development of the studied indices. BQI, AMBI and BENTIX development was based on the relationship between macrofaunal communities and gradients of increasing organic matter input related to either urban effluents or eutrophication processes (Pearson and Rosenberg, 1978; Glémarec and Hily, 1981; Grall and Glémarec, 1997; Borja et al., 2000; Rosenberg et al., 2004). It was thus not surprising that in muddy environments, where sediment organic matter is naturally high, such indices displayed limitations despite their wide applicability to various sources of impact (Borja et al., 2003; Salas et al., 2004; Muniz et al., 2005; Muxika et al., 2005). As a consequence, these indices express worse quality in naturally muddy environments. The fact that Shannon index had a slight tendency to increase in finer sediments is due to the importance of species richness and to the lack of ecological considerations in the formulae. This index will always increase with species richness, although such tendency is not necessarily correlated with good water quality. This phenomenon was noted by different authors (e.g. Dauvin, 2006; Quintino et al., 2006) but few studies have addressed this particular issue. With regard to these observations, the case of Zostera noltii beds where the sediment silt - clay content is high (Blanchet et al., 2004) and which 
were classified as 'Moderate' or even 'Poor' (Fig. 4) by most indices was particularly demonstrating. Indeed, extensive intertidal seagrass beds are considered elsewhere as indicators of a good environmental quality with respect to eutrophication (Tagliapietra et al., 1998; Sfriso et al., 2001; Salas et al., 2004).

Finally, our study evidenced the effect of emersion on these biotic index values and classification (Fig. 4). This environmental factor is a source of natural stress for aquatic species (Cottet et al., 2007). Species adapted to emersion usually become dominant in such an environment and biotic indices such as AMBI, BENTIX or BQI classify these communities as of a low EcoQ status. It is also important to highlight that most BI used in this study were originally developed for subtidal communities. For intertidal environments, the thresholds between EcoQ classes should be revised and 'acceptable' and 'not acceptable' redefined.

The assessment of the EcoQ status of the Seine Estuary was problematic, as we were unable to determine which part of biotic index variability was attributable to pollution-induced perturbations and which part to habitat characteristics. Moreover, using the BOPA, AMBI and BENTIX classifications, the Seine Estuary appeared in a less degraded condition than the two coastal lagoons studied here. This is in complete contradiction with what is known about the low pollution levels of these sites compared to that of the Seine Estuary (Dauvin et al., 2005, 2007). In contrast, the BQI and Shannon indices classified the Seine Estuary as of lower ecological quality status, which was more consistent with the pollution level of this site. However, in such transitional waters, the salinity variation effect has to be taken into account as shown by Zettler at al. (2007) in the Southern Baltic Sea.

In contrast with the other BIs tested here, the BOPA showed relative independence to the habitat characteristics studied here. Indeed this index is not based on the same ecological model of sensitivity/tolerance of species to increasing organic matter input. This index was primarily developed to assess the impact of oil spills on benthic invertebrate communities, as amphipods, the main component of BOPA, are recognised to be sensitive to hydrocarbons (Gomez Gesteira and Dauvin, 2000, 2005; Dauvin and Ruellet, 2007). As a consequence, it did not carry the same bias than the AMBI, BENTIX and BQI for its adaptation to naturally muddy sites. 


\section{Conclusions and Recommendations}

This study highlighted some limitations of currently available biotic indices for the implementation of the WFD in particular biotopes occurring in semi-enclosed coastal ecosystems and transitional waters and the need to adapt these Biotic Indices to habitat specificity. This implies that (1) reference conditions should be determined for each type of habitat and (2) thresholds between EcoQ classes should be adjusted. The definition of reference condition is required by the WFD. The type of habitat and habitat-specific definition of reference conditions is gradually being included in current development of bio-assessment tools. It is the case with the AMBI with the recent development of the Multivariate AMBI (M-AMBI). This tool accounts for reference conditions and includes ShannonWiener diversity index, number of species and AMBI for assessing EcoQ (Borja et al., 2007; Muxika et al., 2007). Concerning the definition of thresholds, one main issue deals with the definition of intervals between EcoQ classes. As an example, Rosenberg et al. (2004) used equal sized intervals for the definition of their EcoQ classes based on BQI. This way of defining classes remains highly subjective and can not be considered as satisfactory because it carries very few ecological meaning. On the other hand, Muxika et al. (2005) defined EcoQ classes on a more ecologically meaningful basis. AMBI was indeed scaled according to the shifts in dominance pattern of the five Ecological Groups they defined. However, the new M-AMBI defines EcoQ classes in a different way with the risk of losing the ecologically meaning of the former classification of the AMBI (see Muxika et al., 2005 and Borja et al., 2007). Moreover, on a more practical approach, scientists have to carefully assess the threshold between what is an 'acceptable' state for benthic communities and what is not (Dauvin, 2007) which should be translated, on a manager point of view, as: where do we need to spend resources to restore the ecosystem and where do we don't? It means that, following the WFD, the threshold between the 'Good' EcoQ status and the 'Moderate' EcoQ status has to be very carefully defined by the scientists. We think that some of these problems may be partially solved by integrating several of the Bs used here (e.g. the AMBI and the BOPA, which seem to generally perform better in the case of our study sites) into a multi-criteria approach such as those developed in the United States (Weisberg et al., 1997; Eaton, 2001; Llanso et al., 2002a,b; Ranasinghe et al., 2002). These 
approaches, like the M-AMBI, would better fit the WFD requirements (Muxika et al., 2007) because they include other metrics describing the benthic community integrity (e.g. abundance, biomass, diversity or tropic guilds). In such an approach, one may be able to define, for each metric or BI, what is not significantly different or do not depart from natural background variability and classify it as 'acceptable'.'Not acceptable' state would be defined for each metric when measured values would be significantly different or depart from natural background variability. Combining the results for each metrics properly would ease to define than the five-level EcoQ classes of the WFD (Llanso et al., 2002b; Aubry and Elliott, 2006; Dauvin, 2007) based on the EcoQ ratio required by the WFD (Borja et al., 2007). Finally, we think that bimodal response of metrics and BIs have to be considered. This means that one should not always interpret the direction of variation of a given metric (e.g. AMBI, H') as a degradation (if the index increases (AMBI) / decreases ( $\left.\mathrm{H}^{\prime}\right)$ ) or a restoration (if the index decreases (AMBI) / increases ( $\left.\mathrm{H}^{\prime}\right)$ ) but instead use the different metrics as indicators of change. This last point may allow, in theory, to assess habitat change in a given ecosystem, which is one of the perturbation that has not yet receive much attention despite its importance, particularly in estuarine ecosystems (Dauvin, 2007).

Acknowledgements: Authors wish to thank every people who, at one moment or another, provided valuable help in the sample collection in the field. We would also like to thank two anonymous referees for their critical review of the first version of the manuscript and for their useful comments. We would also like to thank J.-C. Granger for helping us to improve the quality of the first version of the manuscript. Benthos sampling was financed by Syndicat Mixte du Bassin d'Arcachon and UMR EPOC for Arcachon Bay, by Conseil Général de la Charente-Maritime and Ifremer for MarennesOléron Bay and through the Seine-Aval programme coordinated by the Haute Normandie Region for the Seine Estuary. This work was supported by the French Ministry of Ecology and Sustainable Development (MEDD) through the QuaLiF project ("Directive Cadre Européenne sur l'Eau”, resp.: X. de Montaudouin) from the LITEAU 2 scientific programme. 


\section{References}

Aubry, A. and Elliott, M., 2006. The use of environmental integrative indicators to assess seabed disturbance in estuaries and coasts: application to the Humber estuary, UK. Mar. Pollut. Bull. 53, 175-185.

Auby, I. and Labourg, P.-J., 1996. Seasonal dynamics of Zostera noltii Hornem in the Bay of Arcachon, France. J. Sea Res. 35, 269-277.

Bachelet, G., de Montaudouin, X. and Dauvin, J.-C., 1996. The quantitative distribution of subtidal macrozoobenthic assemblages in Arcachon Bay in relation to environmental factors: a multivariate analysis. Estuar. Coast. Shelf Sci. 42, 371-391.

Bachelet, G., de Montaudouin, X., Auby, I. and Labourg, P.-J., 2000. Seasonal changes in macrophyte and macrozoobenthos assemblages in three coastal lagoons under varying degrees of eutrophication. ICES J. Mar. Sci. 57, 1495-1506.

Bellan, G., 1993. Les espèces indicatrices de pollution et leur repérage en milieu marin: l'exemple des polychètes. Biosystema 10, 45-60.

Beukema, J.J. and Cadée, G. C., 1986. Zoobenthos responses to eutrophication in the Dutch Wadden Sea. Ophelia 26, 55-64.

Blanchet, H., de Montaudouin, X., Lucas, A. and Chardy, P., 2004. Heterogeneity of macrozoobenthic assemblages within a Zostera noltii seagrass bed: diversity, abundance, biomass and structuring factors. Estuar. Coast. Shelf Sci. 61, 111-123.

Borja, A., 2005. The European water framework directive: A challenge for nearshore, coastal and continental shelf research. Cont. Shelf Res. 25, 1768-1783.

Borja, A., Franco, F. and Pérez, V., 2000. A marine biotic index to establish the ecological quality of soft-bottom benthos within European estuarine and coastal environments. Mar. Pollut. Bull. 40, 1100-1114. 
Borja, A. and Heinrich, H., 2005. Implementing the European Water Directive: The debate continues. Mar. Pollut. Bull. 50, 486-488.

Borja, A., Josefson, A. B., Miles, A., Muxika, I., Olsgard, F., Phillips, G., Rodríguez, J. G. and Rygg, B., 2007. An approach to the intercalibration of benthic ecological status assessment in the North Atlantic ecoregion, according to the European Water Framework Directive. Mar. Pollut. Bull. 55, 42-52.

Borja, A., Muxika, I. and Franco, F., 2003. The application of a Marine Biotic Index to different impact sources affecting soft-bottom benthic communities along European coasts. Mar. Pollut. Bull. 46, 835-845.

Castel, J., Caumette, P. and Herbert, R., 1996. Eutrophication gradients in coastal lagoons as exemplified by the Bassin d'Arcachon and the Etang du Prévost. Hydrobiologia 329, 9-28.

Cottet, M., de Montaudouin, X. and Blanchet, H., 2007. Spartina anglica eradication esperiment and in situ monitoring assess structuring strength of habitat complexity on marine macrofauna at high tidal level. Estuar. Coast. Shelf Sci. In press.

Dauvin, J.-C., 1993. Le benthos: témoin des variations de l'environnement. Océanis 19, 25-53. Dauvin, J. C., 2005. Expertise in coastal zone environmental impact assessments. Mar. Pollut. Bull. 50, 107-110.

Dauvin, J. C., 2007. Paradox of estuarine quality: Benthic indicators and indices, consensus or debate for the future. Mar. Pollut. Bull. 55, 271-280.

Dauvin, J.-C., Desroy, N., Janson, A. L., Vallet, C. and Duhamel, S., 2005. Recent changes in estuarine benthic and suprabenthic communities resulting from the development of harbour infrastructure. Mar. Pollut. Bull. 53, 80-90.

Dauvin, J. C. and Ruellet, T., 2007. Polychaete/amphipod ratio revisited. Mar. Pollut. Bull. $55,215-224$. 
Dauvin, J. C., Ruellet, T., Desroy, N. and Janson, A. L., 2007. The ecological quality status of the Bay of Seine and Seine Estuary: use of biotic indices. Mar. Pollut. Bull. 55, 241-257.

Diaz, R. J., Solan, M. and Valente, R. M., 2004. A review of approaches for classifying benthic habitats and evaluating habitat quality. J. envir. Mgm. 73, 165-181.

Eaton, L., 2001. Development and validation of biocriteria using benthic macroinvertebrates for North Carolina estuarine waters. Mar. Pollut. Bull. 42, 23-30.

Fano, E. A., Mistri, M. and Rossi, R., 2003. The ecofunctionnal quality index EQI: a new tool for assessing lagoonal ecosystem impairment. Estuar. Coast. Shelf Sci. 56, 709-716.

Glémarec, M. and Hily, C., 1981. Perturbations apportées à la macrofaune benthique de la baie de Concarneau par les effluents urbains et portuaires. Acta Oecol. 2, 139-150.

Gomez Gesteira, J. L. and Dauvin, J. C., 2000. Amphipods are good bioindicators of the impact pf oil spills on soft-bottom macrobenthic communities. Mar. Pollut. Bull. 40, 10171027.

Gomez Gesteira, J. L. and Dauvin, J.-C., 2005. Impact of the Aegean Sea oil spill on the subtidal fine sand macrobenthic community of the Ares-Betanzos Ria Northern Spain. Mar. Environ. Res. 60, 289-316.

Grall, J. and Glémarec, M., 1997. Using biotic indices to estimate macrobenthic community perturbations in the Bay of Brest. Estuar. Coast. Shelf Sci. 44 suppl. A, 43-53.

Héral, M., Berthome, J.-P., Razet, D. and Garnier, J., 1978. Etude hydrobiologique du bassin de Marennes-Oléron. Un exemple: la sécheresse de l'été 1976. Rev. Trav. Inst. Scient. Tech. Pêches Marit. 42, 269-290.

Héral, M., Razet, D., Deslous-Paoli, J.-M., Manaud, F., Truquet, I. and Garnier, J., 1984. Hydrobiologie du Bassin de Marennes-Oléron. Résultats du Réseau National d'Observation: 1977 à 1981. Ann. Soc. Sci. Nat. Charente-Maritime 7, 259-277. 
Hurlbert, S. H., 1971. The nonconcept of species diversity: a critique and alternative parameters. Ecology 52, 577-586.

Labrune, C., Amouroux, J.-M., Sarda, R., Dutrieux, E., Thorin, S., Rosenberg, R. and Grémare, A., 2005. Characterization of the ecological quality of the coastal Gulf of Lions (NW Mediterranean). A comparative approach based on three biotic indices. Mar. Pollut. Bull. 52, 34-47.

Llanso, R. J., Scott, L. C., Dauer, D. M., Hyland, J. L., Russel, D. E. and Kutz, F. W., 2002a. An estuarine benthic index of biotic integrity for the Mid-Atlantic region of the United States. I. Classification of assemblages and habitat definition. Estuaries 25, 1219-1230.

Llanso, R. J., Scott, L. C., Hyland, J. L., Dauer, D. M., Russel, D. E. and Kutz, F. W., 2002b. An estuarine benthic index of biotic integrity for the Mid-Atlantic region of the United States. II. Index development. Estuaries 25, 1231-1242.

Mouny, P., Dauvin, J. C., Bessineton, C., Elkaim, B. and Simon, S., 1998. Biological components from the Seine Estuary: first results. In: J.-C. Amiard, B. L. Rouzic, B. Berthet and G. Bertru (Editors), Oceans, Rivers and Lakes: Energy and Substance Transfers at Interfaces. Kluwer Academic Publishers, Dordrecht. 333-347.

Muniz, P., Venturini, N., Pires-Vanin, A. M. S., Tommasi, L. R. and Borja, A., 2005. Testing the applicability of a Marine Biotic Index AMBI to assessing the ecological quality of softbottom benthic communities, in the South America Atlantic region. Mar. Pollut. Bull. 50, 624-637.

Muxika, I., Borja, A. and Bald, J., 2007. Using historical data, expert judgement and multivariate analysis in assessing reference conditions and benthic ecological status, according to the European Water Framework Directive. Mar. Pollut. Bul. 55, 16-29

Muxika, I., Borja, A. and Bonne, W., 2005. The suitability of the marine biotic index AMBI to new impact sources along European coasts. Ecol. Indic. 5, 19-31. 
Pearson, J. C. and Rosenberg, R., 1978. Macrobenthic succession in relation to organic enrichment and pollution of the marine environment. Oceanogr. Mar. Biol. Annu. Rev. 16, 229-311.

Pigeot, J., Miramand, P., Guyot, T., Sauriau, P. G., Fichet, D., Le Moine, O. and Huet, V., 2006. Assessment of cadmium pathways in an exploited intertidal ecosystem with chronic Cd inputs: Marennes-Oléron, Atlantic coast, France. Mar. Ecol. Prog. Ser. 307, 101-114.

Quinitino, V., Elliott, M. and Rodrigues, A. M., 2006. The derivation, performance and role of univariate and multivariate indicators of benthic change: Case studies at different spatial scales. J. Exp. Mar. Biol. Ecol. 330, 368-382.

Ranasinghe, J. A., Frithsen, J. B., Kutz, F. W., Paul, J. F., Russel, D. E., Batiuk, R. A., Hyland, J. L., Scott, J. and Dauer, D. M., 2002. Application of two indices of benthic community condition in Chesapeake Bay. Environmetr. 13, 499-511.

Reiss, H. and Kröncke, I., 2005. Seasonal variability of benthic indices: An approach to test the applicability of different indices for ecosystem quality assessment. Mar. Pollut. Bull. 50, 1490-1499.

Rosenberg, R., Blomqvist, M., Nilsson, H. C., Cederwall, H. and Dimming, A., 2004. Marine quality assessment by use of benthic species-abundance distributions: a proposed new protocol within the European Union Water Framework Directive. Mar. Pollut. Bull. 49, 728739.

Salas, F., Neto, J. M., Borja, A. and Marques, J. C., 2004. Evaluation of the applicability of a marine biotic index to characterize the status of estuarine ecosystems: the case of Mondego estuary Portugal. Ecol. Indic. 4, 215-225.

Sfriso, A., Birkemeyer, T. and Ghetti, P. F., 2001. Benthic macrofauna changes in areas of Venice lagoon populated by seagrasses or seaweeds. Mar. Environ. Res. 52, 323-349.

Scherrer, B., 1984. Biostatistique. Gaëtan Morin, Montréal. 850 pp. 
Siegel, S., 1956. Nonparametric statistics for the behavioral sciences. Mc Graw-Hill Book Company, New York. 212 pp.

Simboura, N., 2004. Benthic Index vs. Biotic Index in monitoring: an answer to Borja et al., 2003. Mar. Pollut. Bull. 48, 404-405.

Simboura, N., Panayotidis, P. and Papathanassiou, E., 2005. A synthesis of the biological quality elements for the implementation of the European Water Framework Directive in the Mediterranean ecoregion: The case of Saronikos Gulf. Ecol. Indic. 5, 253-266.

Simboura, N. and Reizopoulou, S., 2007. A comparative approach of assessing ecological status in two coastal areas of Eastern Mediterranean. Ecol. Indic. In press.

Simboura, N. and Zenetos, A. 2002. Benthic indicators to use in Ecological Quality classification of Mediterranean soft bottom marine ecosystems, including a biotic index. Mediterr. Mar. Sci. 3, 77-111.

Tagliapietra, D., Pavan, M. and Wagner, C., 1998. Macrobenthic community changes related to eutrophication in Palude della Rosa, Venetian Lagoon, Italy. Est. Coast. Mar. Sci. 47, 217 226.

Warwick, R. M., 1986. A new method for detecting pollution effects on marine macrobenthic communities. Mar. Biol. 92, 557-562.

Weisberg, S. B., Ranasinghe, J. A., Dauer, D. M., Schaffner, L. C., Diaz, J. D. and Frithsen, J. B., 1997. An estuarine benthic index of biotic integrity B-IBI for Chesapeake Bay. Estuaries $20,140-158$.

Zettler, M. L., Schiedek, D. and Boberz, B., 2007. Benthic biodiversity indices versus salinity gradient in the southern Baltic Sea. Mar. Pollut. Bull. 55, 258-270. 
Table 1

Characteristics of the three datasets used in this study: number of stations, sampling device, mesh size, and years of sampling. All stations were sampled once.

\begin{tabular}{lccc}
\hline & Arcachon Bay & Marennes-Oléron Bay & Seine Estuary \\
\cline { 2 - 4 } $\begin{array}{l}\text { Number of } \\
\text { stations }\end{array}$ & 177 & 262 & 111 \\
Sampling device & $\begin{array}{c}\text { Ekman grab \& Box } \\
\text { corer }\left(0.045 \mathrm{~m}^{2}\right)\end{array}$ & $\begin{array}{c}\text { Smith-McIntyre grab } \\
\& \text { Box corer }\left(0.1 \mathrm{~m}^{2}\right)\end{array}$ & various grabs \\
Mesh size & $1 \mathrm{~mm}$ & $1 \mathrm{~mm}$ & 1 or $2 \mathrm{~mm}$ \\
$\begin{array}{l}\text { Location of } \\
\text { stations }\end{array}$ & 89 subtidal & 135 subtidal & 111 subtidal \\
Sampling years & 2002 & 127 intertidal & $1993-2002$ \\
& & 1995 & \\
\hline
\end{tabular}


Table 2

Indices calculated from macrobenthos databases. For the AMBI: \%GI: relative abundance of disturbance-sensitive species; \%GII: relative abundance of disturbance-indifferent species; \%GIII: relative abundance of disturbance-tolerant species; \%GIV: relative abundance of second-order opportunistic species; $\% \mathrm{GV}$ : relative abundance of first-order opportunistic species. For the BENTIX: \%GS: relative abundance of sensitive species $=\% \mathrm{GI}+\% \mathrm{GII} ; \% \mathrm{GT}$ $=$ relative abundance of tolerant species $=\% \mathrm{GIII}+\% \mathrm{GIV}+\% \mathrm{GV}$. For the Shannon index: $n_{i}$ : number of individuals belonging to the $i$ th species; $\mathrm{N}$ : total number of individuals. For the BOPA: $f p$ : opportunistic polychaetes frequency; $f a=$ amphipods frequency (except Jassa sp.). For the BQI: $\mathrm{S}$ : number of species in the sample; $A_{i}=$ total abundance of $i$ th species in the sample; $\mathrm{ES}(50)_{0.05 i}$ : $\mathrm{ES}(50)_{0.05}$ of the $i$ th species; tot $A=$ total abundance of the individuals belonging to the species for which $\mathrm{ES}(50)_{0.05}$ can be computed.

\begin{tabular}{lll}
\hline Biotic index & Algorithms & References \\
\hline AMBI & {$[(0 \times \% \mathrm{GI})+(1.5 \times \% \mathrm{GII})+(3 \times \% \mathrm{GIII})+((4.5 \times$} & $\begin{array}{l}\text { Borja et al. } \\
(2000)\end{array}$ \\
BENTIX & $(6 \times \% \mathrm{GIV})+(6 \times \% \mathrm{GV})] / 100$ & $\begin{array}{l}\text { Simboura and } \\
\text { Zenetos } \\
(2002)\end{array}$ \\
Shannon index & $-\sum\left[\left(\frac{n_{i}}{N}\right) \times \log _{2}\left(\frac{n_{i}}{N}\right)\right]$ & Pielou (1975) \\
BOPA & $10 \log \left[\frac{f p}{(f a+1)}+1\right]$ & \\
BQI & $\left(\sum_{i=1}^{s}\left(\frac{A i}{\operatorname{tot} A} \times \mathrm{ES}(50)_{0.05 i}\right)\right) \times{ }^{10} \log (\mathrm{S}+1)$ & $\begin{array}{l}\text { Dauvin and } \\
\text { Ruellet (2007) }\end{array}$ \\
& with & $\begin{array}{l}\text { Rosenberg et } \\
\text { al. (2004) }\end{array}$ \\
& $E S(50)=1-\sum_{i=1}^{s} \frac{\left(N-N_{i}\right) !(N-50) !}{\left(N-N_{i}-50\right) ! N !}$ & \\
& & \\
\hline
\end{tabular}


Table 3

Ecological Quality (EcoQ) status classes and thresholds used to classify index values in this study.

\begin{tabular}{|c|c|c|c|c|c|c|}
\hline \multicolumn{7}{|c|}{ EcoQ status } \\
\hline & High & Good & Moderate & Poor & Bad & References \\
\hline $\begin{array}{l}\text { Shannon } \\
\text { Diversity }\end{array}$ & $>4$ & $4-3$ & $3-2$ & $2-1$ & $<1$ & Labrune et al., 2005 \\
\hline AMBI & $0-1.2$ & $1.2-3.3$ & $3.3-4.3$ & $4.3-5.5$ & $>5.5$ & Muxika et al., 2005 \\
\hline $\begin{array}{l}\text { BENTIX for } \\
\text { sands }\end{array}$ & $6-4.5$ & $4.5-3.5$ & $3.5-2.5$ & $2.5-2$ & 0 & $\begin{array}{l}\text { Simboura and Zenetos, } \\
2002\end{array}$ \\
\hline $\begin{array}{l}\text { BENTIX for } \\
\text { muds }\end{array}$ & $6-4$ & $4-3$ & $3.0-2.5$ & $2.5-2$ & 0 & $\begin{array}{l}\text { Simboura and Zenetos, } \\
2002\end{array}$ \\
\hline BOPA & $0-0.04576$ & $\begin{array}{c}0.04576- \\
0.13966\end{array}$ & $\begin{array}{c}0.13966- \\
0.19382\end{array}$ & $\begin{array}{c}0.19382- \\
0.26761\end{array}$ & $\begin{array}{c}0.0 .26761- \\
0.30103\end{array}$ & Dauvin et Ruellet, in press \\
\hline $\begin{array}{l}\text { BQI Seine } \\
\text { estuary }\end{array}$ & $11.5-9.2$ & $9.2-6.9$ & $6.9-4.6$ & $4.6-2.3$ & $2.3-0$ & $\begin{array}{l}\text { This study; Rosenberg et } \\
\text { al., } 2004\end{array}$ \\
\hline $\begin{array}{l}\text { BQI Marennes- } \\
\text { Oléron bay } \\
\text { (intertidal) }\end{array}$ & $10-8$ & $8-6$ & $6-4$ & $4-2$ & $2-0$ & $\begin{array}{l}\text { This study; Rosenberg et al., } \\
2004\end{array}$ \\
\hline $\begin{array}{l}\text { BQI Marennes- } \\
\text { Oléron bay } \\
\text { (subtidal) }\end{array}$ & $17.9-14.3$ & $14.3-10.7$ & $10.7-7.1$ & $7.1-3.6$ & $3.6-0$ & $\begin{array}{l}\text { This study; Rosenberg et al., } \\
2004\end{array}$ \\
\hline $\begin{array}{l}\text { BQI Arcachon } \\
\text { bay (intertidal) }\end{array}$ & $13-10.4$ & $10.4-7.8$ & $7.8-5.2$ & $5.2-2.6$ & $2.6-0$ & $\begin{array}{l}\text { This study; Rosenberg et al., } \\
2004\end{array}$ \\
\hline $\begin{array}{l}\text { BQI Arcachon } \\
\text { bay (subtidal) }\end{array}$ & $12.8-10.2$ & $10.2-7.6$ & $7.6-5.0$ & $5.0-2.4$ & $2.4-0$ & $\begin{array}{l}\text { This study; Rosenberg et al., } \\
2004\end{array}$ \\
\hline
\end{tabular}




\section{Table 4}

Levels used for the measurement of agreement/disagreement between biotic indices for each station. Overall, full agreement was measured as [a]+[f], partial agreement was measured as $[\mathrm{b}]+[\mathrm{e}]$ and disagreement as $[\mathrm{c}]+[\mathrm{d}]$.

\begin{tabular}{cll}
\hline $\begin{array}{l}\text { Sum of } \\
\text { scores }\end{array}$ & Interpretation & \\
\hline 0 & $\begin{array}{l}\text { Full agreement of the } 5 \text { biotic indices on 'Moderate' or worse EcoQ status } \\
\text { ('not acceptable') }\end{array}$ & [a] \\
1 & $\begin{array}{l}\text { Partial agreement (4 agreements out of } 5 \text { biotic indices) of the } 5 \text { biotic } \\
\text { indices on 'Moderate' or worse EcoQ status ('not acceptable') }\end{array}$ & {$[\mathrm{b}]$} \\
2 & $\quad \begin{array}{ll}\text { Disagreement between the } 5 \text { biotic indices on the EcoQ status of the station } \\
3\end{array}$ & $\begin{array}{l}\text { Disagreement between the } 5 \text { biotic indices on the EcoQ status of the station } \\
\text { [d] }\end{array}$ \\
4 & $\begin{array}{l}\text { Partial agreement (4 agreements out of } 5 \text { biotic indices) of the } 5 \text { biotic } \\
\text { indices on 'Good' or higher EcoQ status ('acceptable') }\end{array}$ \\
& $\begin{array}{l}\text { Full agreement of the } 5 \text { biotic indices on 'Good' or better EcoQ status } \\
\text { ('acceptable') }\end{array}$ \\
\hline
\end{tabular}




\section{Table 5}

Significant, very significant and highly significant results of the non-parametric sign test conducted on the datasets of Arcachon Bay, Marennes-Oléron Bay and the Seine Estuary. Level of significance is indicated (***: highly significant, $\mathrm{p}<0.001$; $* *$ : very significant, $\mathrm{p}<0.01$; *: significant, $\mathrm{p}<0.05$; ns: not significant, $\mathrm{p}>0.05$ ).

\begin{tabular}{lllll}
\hline $\begin{array}{l}\text { Arcachon } \\
\text { Bay }\end{array}$ & BENTIX & BOPA & BQI & $\begin{array}{l}\text { Shannon } \\
\text { index }\end{array}$ \\
\hline AMBI & $* * *$ & $*$ & $* * *$ & $* * *$ \\
BENTIX & & $* * *$ & $* * *$ & $\mathrm{~ns}$ \\
BOPA & & & $* * *$ & $* * *$ \\
BQI & & & & $* * *$ \\
\hline Marennes- & \multirow{2}{*}{ BENTIX } & BOPA & BQI & Shannon \\
Oléron Bay & $* * *$ & $\mathrm{~ns}$ & $* * *$ & $* * *$ \\
\hline AMBI & $* * *$ & ns & $* * *$ \\
BENTIX & & $* * *$ & $* * *$ & $* * *$ \\
BOPA & & & & $* * *$ \\
BQI & & & BQI & Shannon \\
\hline Seine & \multirow{2}{*}{ BENTIX } & BOPA & index \\
Estuary & $* *$ & $\mathrm{~ns}$ & $* * *$ & $* * *$ \\
AMBI & & $* *$ & $* * *$ & $* * *$ \\
BENTIX & & & $* * *$ & $* * *$ \\
BOPA & & & & $\mathrm{ns}$ \\
BQI & & & & \\
\hline
\end{tabular}


Table 6

Results of the non-parametric Kendall's rank correlation coefficient-test between Biotic Indices-derived Ecological Quality (EcoQ) status classifications (with the five EcoQ classes defined by the WFD namely 'High', 'Good', 'Moderate', 'Poor' and 'Bad'). Level of significance is indicated $(* * *$ : highly significant, $\mathrm{p}<0.001$; **: very significant, $\mathrm{p}<0.01$; *: significant, $\mathrm{p}<0.05$; ns: not significant, $\mathrm{p}>0.05$ ). These tests were conducted on the pooled data of the two coastal systems (Arcachon and Marennes-Oléron bays).

\begin{tabular}{lllll}
\cline { 2 - 5 } $\mathrm{n}=231$ & BENTIX & BOPA & BQI & SHANNON \\
\cline { 2 - 5 } AMBI & $+0.911 * * *$ & $\mathrm{~ns}$ & $+0.458 * * *$ & $+0.393 * * *$ \\
BENTIX & & $\mathrm{ns}$ & $+0.477 * * *$ & $+0.709 * * *$ \\
BOPA & & & $\mathrm{ns}$ & $-0.365 * * *$ \\
BQI & & & & $+0.522 * * *$ \\
& & & & \\
\hline
\end{tabular}




\section{Table 7}

Results of the non-parametric Kendall's rank correlation coefficient-test between Biotic Indices-derived Ecological Quality (EcoQ) status classifications (with the five EcoQ classes defined by the WFD namely 'High', 'Good', 'Moderate', 'Poor' and 'Bad'). Level of significance is indicated (***: highly significant, $\mathrm{p}<0.001$; $* *$ : very significant, $\mathrm{p}<0.01$; *: significant, $\mathrm{p}<0.05$; ns: not significant, $\mathrm{p}>0.05$ ). These tests were conducted on the data of the Seine Estuary.

\begin{tabular}{lllll}
\cline { 2 - 5 } n=231 & BENTIX & BOPA & BQI & SHANNON \\
\cline { 2 - 5 } AMBI & $+0.999 * * *$ & $\mathrm{~ns}$ & $\mathrm{~ns}$ & $\mathrm{~ns}$ \\
BENTIX & & $\mathrm{ns}$ & $\mathrm{ns}$ & $+0.325 *$ \\
BOPA & & & $\mathrm{ns}$ & $-0.873 * *$ \\
BQI & & & & $+0.679 * * *$ \\
& & & & \\
\hline
\end{tabular}


Table 8

Results of the non-parametric Kruskal - Wallis test comparing the environmental characteristics of stations (sediment silt \& clay content, duration of emersion) between EcoQ classes derived from the five Biotic Indices for Arcachon Bay and Marennes-Oléron Bay stations. In a first approach the full dataset was used, on a second approach tests were performed dividing the datasets into subtidal and intertidal stations. Range of EcoQ is indicated with ' 1 ' corresponding to 'High' EcoQ, 2 to 'Good', 3 to 'Moderate', 4 to 'Poor' and 5 to 'Bad' EcoQ. Level of significance is indicated.

\begin{tabular}{|c|c|c|c|c|}
\hline \multirow[b]{2}{*}{ Arcachon Bay (whole bay) } & \multirow[b]{2}{*}{$\mathrm{n}$} & \multirow[b]{2}{*}{ range of EcoQ } & \multirow{2}{*}{$\begin{array}{c}\% \text { silt \& clays } \\
\text { p-level } \\
(\mathrm{K}-\mathrm{W} \text { test })\end{array}$} & \multirow{2}{*}{$\begin{array}{c}\text { emersion } \\
\text { p-level } \\
(\mathrm{K}-\mathrm{W} \text { test })\end{array}$} \\
\hline & & & & \\
\hline AMBI & 176 & $1-4$ & $* * *$ & $* * *$ \\
\hline BENTIX & 177 & $1-4$ & $* * *$ & $* * *$ \\
\hline BOPA & 176 & $1-3$ & ns & ns \\
\hline BQI & 94 & $1-5$ & $* * *$ & $* * *$ \\
\hline SHANNON & 177 & $1-5$ & $*$ & $* * *$ \\
\hline \multicolumn{5}{|l|}{ Arcachon Bay (intertidal only) } \\
\hline AMBI & 84 & $2-4$ & $* *$ & \\
\hline BENTIX & 85 & $1-4$ & $* * *$ & \\
\hline BOPA & 85 & $1-4$ & ns & \\
\hline BQI & 65 & $1-5$ & $* * *$ & \\
\hline SHANNON & 85 & $1-4$ & $* *$ & \\
\hline \multicolumn{5}{|l|}{ Arcachon Bay (subtidal only) } \\
\hline AMBI & 89 & $1-3$ & $* *$ & \\
\hline BENTIX & 89 & $1-4$ & $* *$ & \\
\hline BOPA & 89 & $1-3$ & $*$ & \\
\hline BQI & 29 & $1-4$ & $*$ & \\
\hline SHANNON & 89 & $1-4$ & $* * *$ & \\
\hline & & & $\%$ silt \& clays & emersion \\
\hline Marennes-Oléron Bay (whole bay) & $\mathrm{n}$ & range of EcoQ & $\begin{array}{c}\text { p-level } \\
\text { (K-W test) }\end{array}$ & $\begin{array}{c}\text { p-level } \\
\text { (K-W test) }\end{array}$ \\
\hline AMBI & 261 & $1-4$ & $* * *$ & ns \\
\hline BENTIX & 261 & $1-4$ & $* * *$ & $* * *$ \\
\hline BOPA & 261 & $1-3$ & ns & ns \\
\hline BQI & 133 & $1-5$ & ns & ns \\
\hline SHANNON & 262 & $1-5$ & $* * *$ & $* * *$ \\
\hline \multicolumn{5}{|l|}{ Marennes-Oléron Bay (intertidal only) } \\
\hline AMBI & 126 & $1-3$ & $* *$ & \\
\hline BENTIX & 126 & $1-4$ & $* * *$ & \\
\hline BOPA & 125 & $1-3$ & ns & \\
\hline BQI & 68 & $1-4$ & ns & \\
\hline SHANNON & 126 & $1-5$ & $* * *$ & \\
\hline \multicolumn{5}{|l|}{ Marennes-Oléron Bay (subtidal only) } \\
\hline AMBI & 135 & $1-4$ & $* * *$ & \\
\hline BENTIX & 135 & $1-4$ & $* * *$ & \\
\hline BOPA & 133 & $1-3$ & ns & \\
\hline BQI & 64 & $1-5$ & $*$ & \\
\hline SHANNON & 135 & $1-5$ & $* * *$ & \\
\hline
\end{tabular}




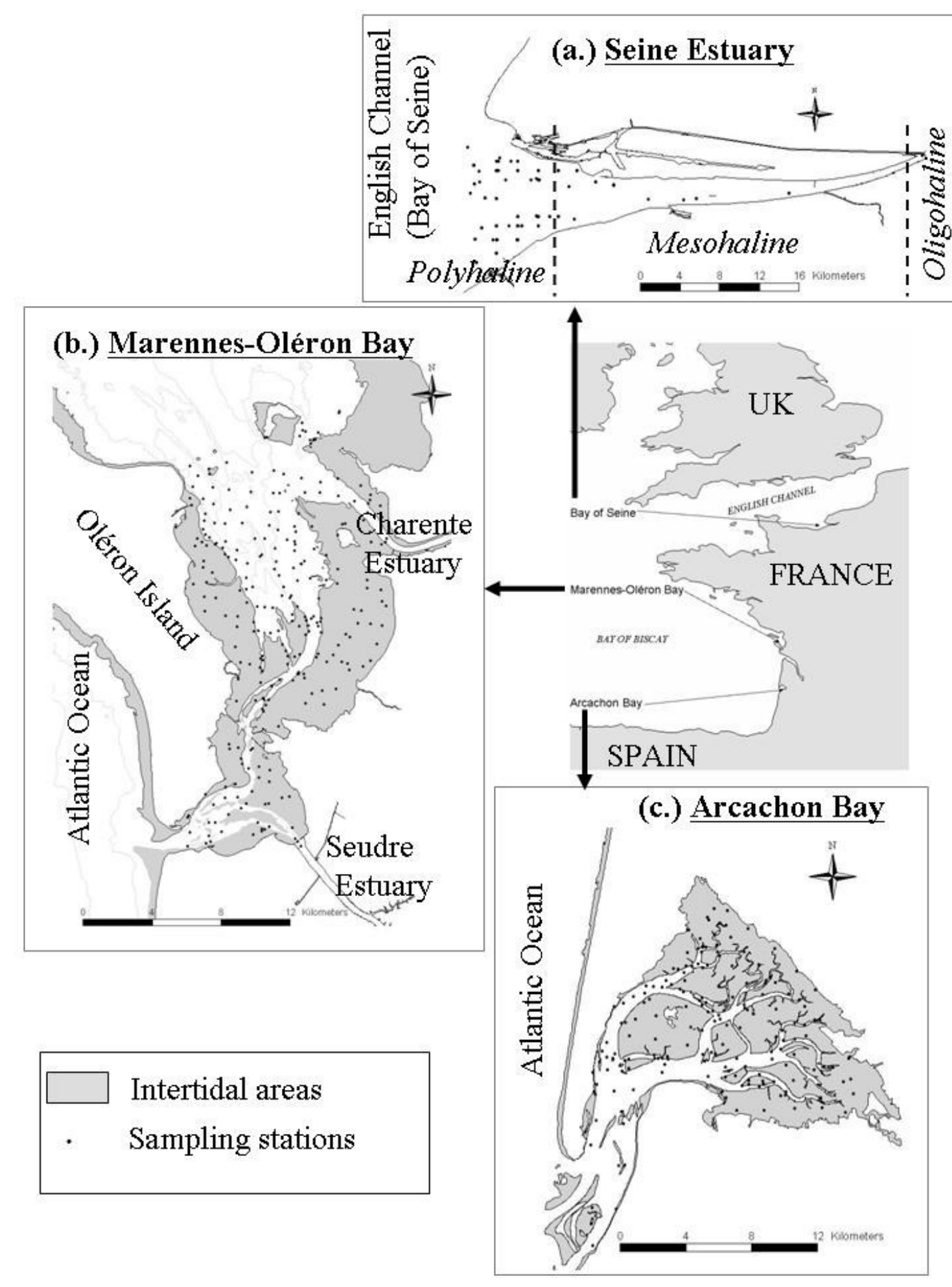


MARENNES-OLERON Bay

a.

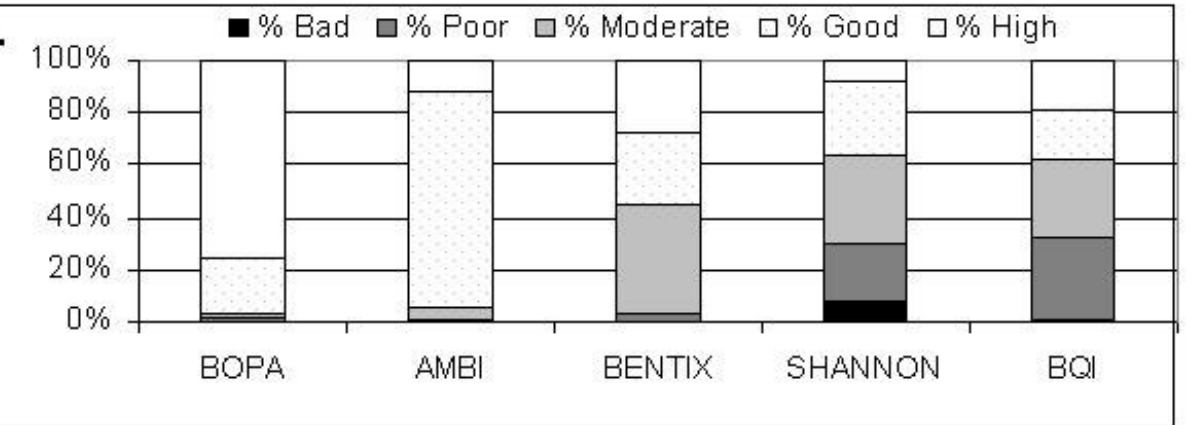

\section{ARCACHON Bay}

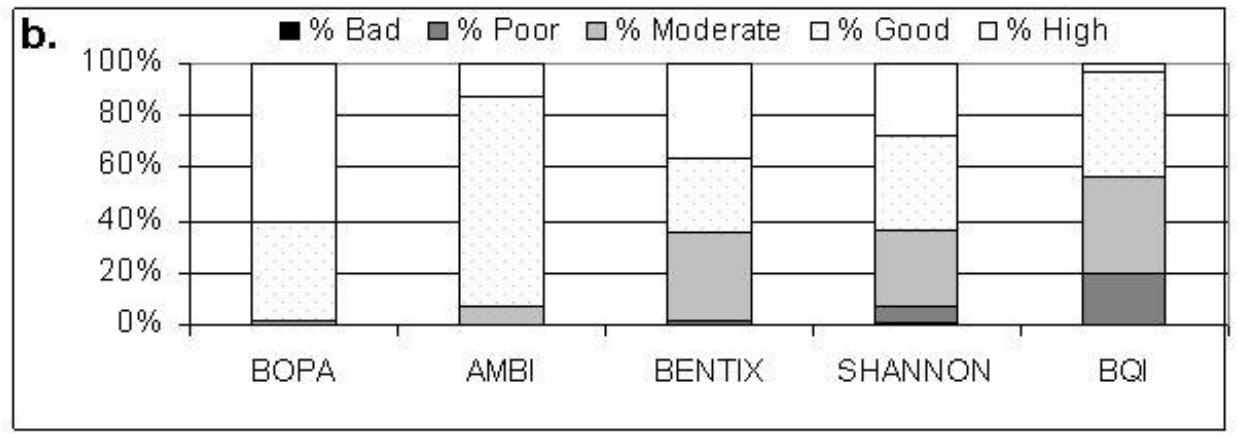

\section{SEINE estuary}

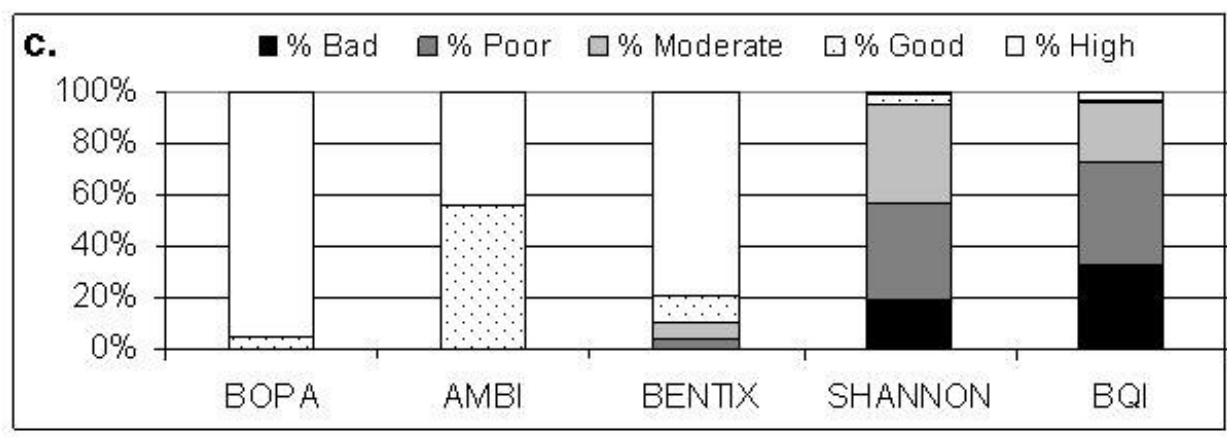

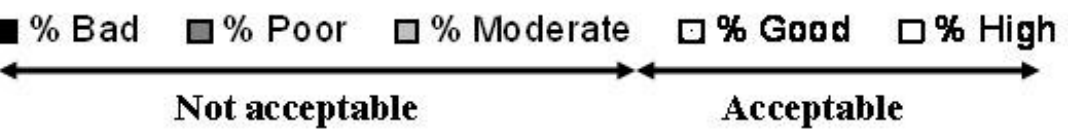




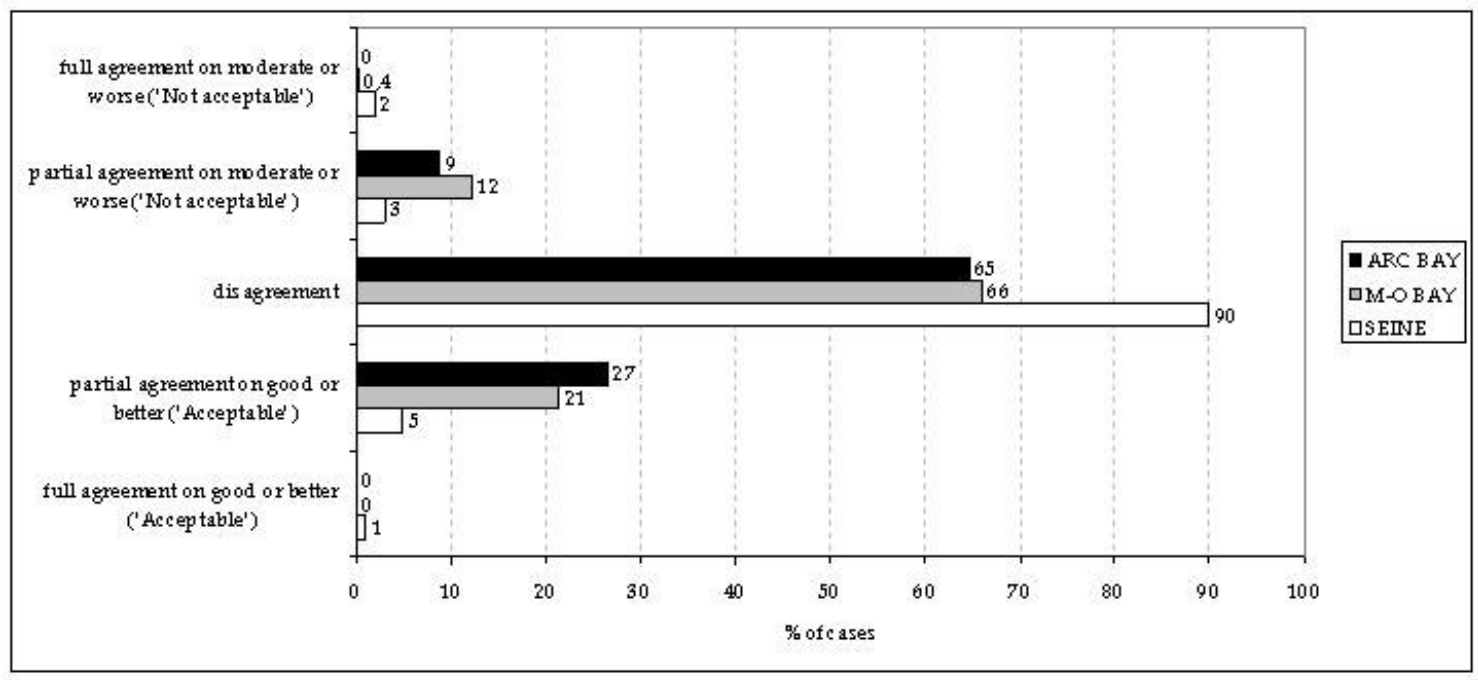




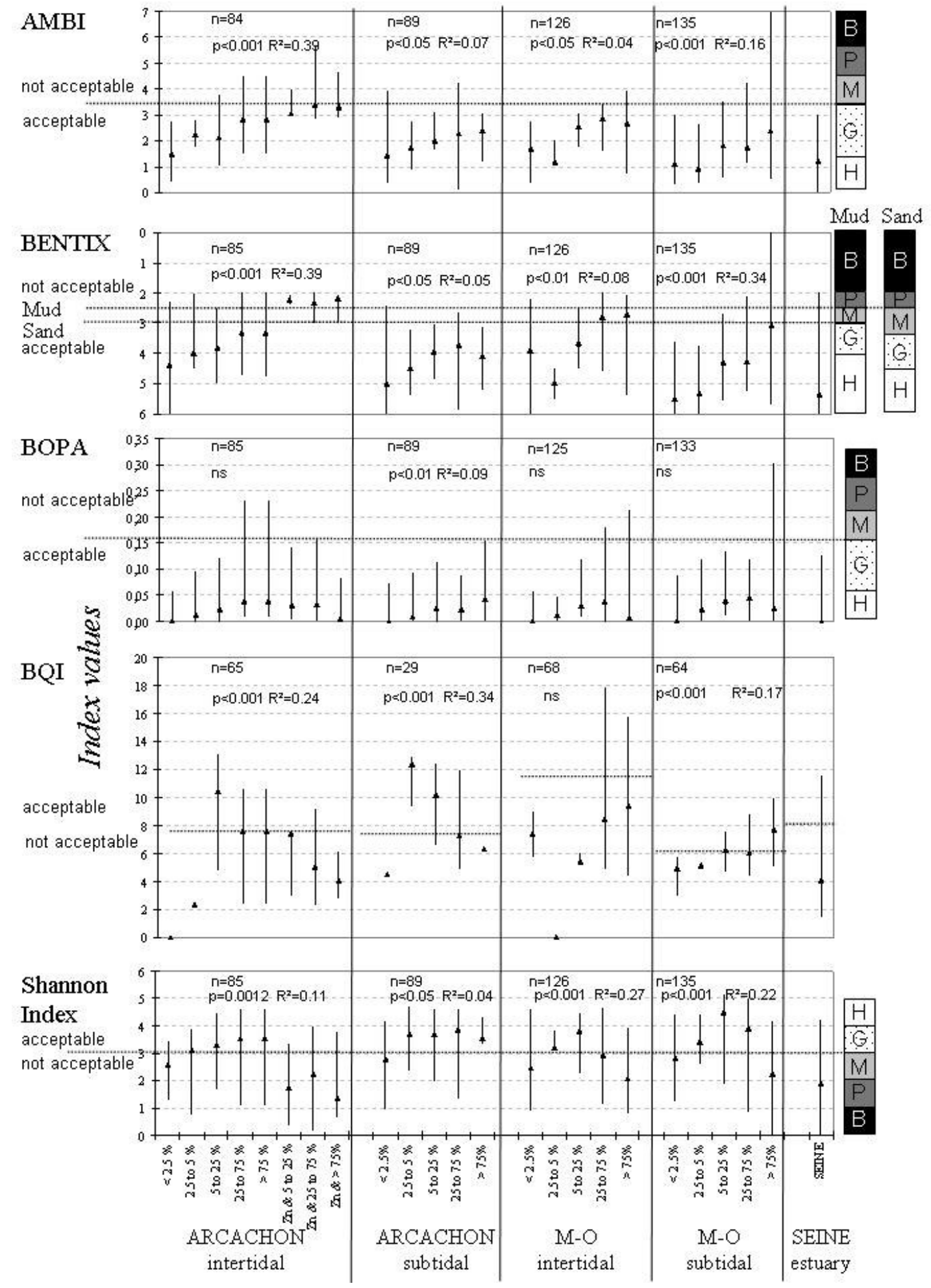

